\title{
Arsenic in France. The Cultures of Poison During the First Half of the Nineteenth Century
}

\author{
José Ramón Bertomeu Sánchez
}

This essay reviews the movement of poisons across different popular, medical and legal cultures during the 1830 s and 1840 s in France. Many French people at that time felt that they were living in a "wave of poisoning crimes", mostly performed by using arsenic, which was regarded as the "king of poisons" during the nineteenth century. Poisons such as arsenic were common materials employed in everyday life for different purposes in agriculture, industry and medicine. They were also frequent protagonists in popular literature, folk tales, theater plays, and other forms of popular culture. At the same time, many poisons were both objects and tools of inquiry in medicine and science. Their composition and deleterious properties had attracted the attention of doctors and natural philosophers since ancient times. With the development of animal experimentation, poisons were increasingly employed as tools for research, whose dramatic physiological effects were employed for investigating the vital functions. From a legal point of view, poisons were criminal tools for performing silent murders, which were very difficult to prove in court. The testimony of regular witnesses was useless due to the secret nature of poisoning crimes, so judges frequently requested the advice of experts in medicine and chemical analysis. Prompted by unexpected situations and puzzling questions, nineteenth-century toxicological research developed along with criminal investigations during poisoning trials. ${ }^{1}$ The toxic effects of arsenic largely depended on the nature of the compounds, the ingested quantity, the nature of the victim and the dosage (from acute to long-term poisoning). Consequently, arsenic presented a great variety in the character, combination, and severity of symptoms, including also perplexing and misleading exceptions. For this reason, a nineteenth-century professor of legal jurisprudence dubbed arsenic as the

1 These issues are discussed in J.R. Bertomeu Sánchez, "Animal Experiments, Vital Forces and Courtrooms: Mateu Orfila, François Magendie and the study of poisons in nineteenth-century France," Annals of Science 69 (2012): 1-26.

(C) JOSÉ RAMÓN BERTOMEU SÁNCHEZ, 2018 | DOI 10.1163/9789004325562_007

This is an open access chapter distributed under the terms of the CC-BY-NC License. 
"very Proteus of poisons", that is, "capable of producing almost every species of poisonous action." ${ }^{2}$

Apart from its criminal uses, arsenic was employed in many other activities in nineteenth-century France: wallpaper pigment, embalming, agriculture, rat poison, veterinary treatments, medical drugs, and so on. Arsenic was among the regular commodities that could be easily found in a nineteenth-century rural house, commonly bought in pharmaceutical shops. And yet, arsenic never enjoyed the material "self-evidence of a slap in the face", which Lorraine Daston attributes to quotidian objects. ${ }^{3}$ Its physical properties (white color and mild taste) were ambiguous and misleading, transforming arsenic into an elusive product, which could be confused with many other quotidian materials: flour, carbonates, salts, and so on. Poisoners largely relied on these properties and terrible accidents and false accusations of poisoning were frequent.

Arsenic was also elusive from the point of view of its detection. As in the case of many other early modern materials reviewed by Emma Spary and Ursula Klein, the existence of arsenic "was never contested, though the ways of its identification as well as its meaning and values were subject to debate." Which tests were the most reliable ones and who was their right interpreter (chemists, doctors, apothecaries) were matters of contention. In short, nineteenth-century arsenic was at once a quotidian material, scientific object, criminal tool and legal concern. Its associated meanings and values were contingent and varied considerably among forensic experts, lawyers, judges or poisoners. However, the historically-located and locally-embedded ontological nature of arsenic was plastic enough to be adapted to the varied needs and expectations of different protagonists. In this sense, arsenic resembles other "boundary objects" studied by historians of science: it could inhabit different

2 "Summary of the lecture delivered by Dr. Donkin, Professor of Medical Jurisprudence at the University of Durham," Pharmaceutical Journal 3 (December 14, 1872): 472, quoted by James C. Whorton, The Arsenic Century: How Victorian Britain was poisoned at home, work, and play (Oxford: Oxford University Press, 2010), 15; For a popular account on the general history of arsenic see John Parascandola, King of Poisons. A history of arsenic (Washington: Potomac Books, 2012).

3 Lorraine Daston, ed., Biographies of Scientific Objects (Chicago: University of Chicago Press, 200o), 2; See also Lorraine Daston, ed., Things That Talk: Object lessons from art and science (New York: Zone Books, 2008).

4 Ursula Klein, Emma Spary, eds., Materials and Expertise in Early Modern Europe: Between market and laboratory (Chicago: University of Chicago Press, 2010), 7-10, on 9. 
social and cultural contexts, encouraging exchanges and interactions among legal, scientific and popular cultures. ${ }^{5}$

This essay explores some of these interactions, circulations and unequal exchanges by following the traces of arsenic in nineteenth-century France. The first section reviews the different uses of arsenic in everyday life, from agriculture to medicine. I remark on its elusive nature regarding color, taste and smell. I discuss also the first attempts of regulating the circulation of dangerous substances in France. The next section deals with the entanglement between the ambiguous identity of arsenic and the different methods employed for detecting mineral poisons during the 1830 . These methods provided different visual and material forms of proof, which were employed for several purposes in laboratories, academies and courtrooms. Attention is paid to the new highsensitivity chemical techniques such as the Marsh test. I also highlight the persistence of old methods, which were employed in different contexts, sometimes for different purposes. The next section deals with expert controversies emerging from poisoning trials and their circulation in newspapers, literature and other forms of popular culture. In the last section, I claim that these movements were multidirectional and involved new problems and challenges for toxicologists in courts.

\section{Ubiquitous: The Many Uses of Arsenic}

Arsenic compounds were employed for a varied range of goals during the nineteenth century. Around 286,00o kg of different arsenic compounds (oxide and

5 On boundary objects, see the famous essay by Susan Leigh Star and James Griesemer, "Institutional Ecology, Translations, and Boundary Objects: Amateurs and professionals in Berkeley's Museum of Vertebrate Zoology, 1907-1939," Social Studies of Science 19 (1988): 387420; On issues related to scientific objects, everyday materials and commodities see Ursula Klein, Wolfgang Lefèvre, Materials in Eighteenth-Century Science. A historical ontology (Cambridge, MA: MIT Press, 2007) and Ursula Klein and Carsten Reinhardt, eds., Objects of Chemical Inquiry (Sagamore Beach, MA: Science History Publications, 2014); For a recent review of the literature see Simon Werrett, "Matter and Facts: Material culture and the history of science," Alison Wylie and Robert Chapman, eds. Material Evidence: Learning from archaeological evidence (London: Routledge, 2014), 339-352. I am grateful to Simon Werrett for this text; On the even more unstable identity of another toxic substance, see Astrid Schrader, "Responding to Pfiesteria Piscicida (The Fish Killer): Phantomatic ontologies, indeterminacy, and the responsibility in toxic microbiology," Social Studies of Science 40 (2010): 275-306; For different typologies of scientific objects see John Law and Vicky Singleton, "Object Lessons," Organization 12 (3) (2005): 331-355. 
sulfur minerals) were consumed annually in France around 1840 (most of these products were imported). ${ }^{6}$ Around forty percent of this quantity was "white arsenic" (or just "arsenic"), the popular term for what contemporary chemists called "arsenious oxide." The names of its sulfides ("orpiment" and "realgar") had ancient origins but these expressions were still popular in the nineteenth and even twentieth century. Other names (such as "Scheele's green") were more recent but also very popular (in contrast with the scientific names such as "arsenite of copper") due to its broad use as a pigment. ${ }^{7}$ Apart from being used as a pigment, arsenic was employed as a component of popular nineteenth-century drugs. The most famous was the Fowler liquor, an alkaline solution of white arsenic, which was introduced by Thomas Fowler during the 1780 s and soon became popular in many European countries, notably after being included in the London Pharmacopeia under the name "Liquor Arsenicalis" in early nineteenth century. It was employed for a broad range of health problems and remained in pharmacopeias until the early twentieth century, when new preparations (the most famous being "Salvarsan") expanded the therapeutic applications of arsenic. ${ }^{8}$

Arsenic compounds were also broadly employed in other activities, for instance, in veterinary pharmacy, taxidermy or funeral embalming. For centuries, this latter practice had been reserved for royalty, but it gained popularity during the 1830 among French bourgeois families. The new imaginary of death emerged along with the discovery of cheaper chemical methods such as those developed by Jean-Nicolas Gannal (1791-1852), a French military apothecary and entrepreneur who became famous for this work. Many of the new methods were based on arsenical solutions introduced by arterial injection. The new embalming technology was so popular and lucrative that many patent litigations took

6 Jules Barse and Adolphe Chevallier, Manuel pratique de l'appareil de Marsh (Paris: Labé, 1843), 8-9; Frédéric Chauvaud, Les experts du crime. La médecine légale en France au XIxè siècle (Paris: Aubier, 2000), 198-199, for more information on poisons in nineteenth-century France. On Britain see Katherine Watson, Poisoned Lives: English poisoners and their victims (London: Hambledon, 2004) and Whorton, The Arsenic century (see note 2).

7 See the diversity of names in a popular chemistry textbook: Thomas Brande, Chemistry (Philadelphia: Blanchard, 1863), 439-446.

8 More details in Parascandola, King of Poisons, pp. 146-151 (see note 2); Fowler's solution was included in French pharmacopeias in early nineteenth-century. See Félix-Séverin Ratier and Etienne-Ossian Henry, Pharmacopée française ou Code des médicaments (Paris: Ballière, 1827), 403-404; Codex Pharmacopée Française (Paris: Bechet, 1857), 117; A limited group of arsenical products were employed in veterinary pharmacy. See Philippe Lébas, Pharmacie vétérinaire, chimique, théorique et pratique (Paris: Lelong, 1836), 49. 
place during the 1830 s and 1840 s in France. ${ }^{9}$ This practice reinforced the popular idea that arsenic possessed the astonishing power of preserving the decay of bodies poisoned with it. Many observations of this kind had been reported in medical literature and even animal experiments were performed with poisoned dogs. After being buried for several months, their "flesh and alimentary canal were found red and fresh, as if pickled."10 In this light, suspicions of poisoning where raised when a corpse was found un-decomposed after being inhumed several months.

The uses of arsenic in the French rural world were also varied during the nineteenth century. A mixture of white arsenic and alum was commonly employed for stepping vegetal grains ("chaulage")." The practice lasted throughout the nineteenth century in spite of frequent accidental poisonings produced by this method and subsequent attempts by the government to banish it. As the chemist Jean-Baptiste Boussingault (1801-1887) acknowledged in 1856, the treatment of grains with arsenic provided two important benefits to farmers: the preservation of the grains and its effects as a pesticide. Even if non-toxic products (such as sodium sulfate chalk or common salt) could easily replace arsenic regarding the first goal, these non-poisoning products could not deter the action of rats and other animals on grains, as many farmers who ever dared to abandon arsenical compounds had dramatically experienced. ${ }^{12}$ This situation explains why arsenic pesticides (such as the popular "Paris green") lasted until the twentieth century in agriculture, in spite of official regulations and frequent accidents. One of the most dramatic cases took place as late as in 1887 in Hyères, when the contamination of vines with arsenic produced eleven deaths and poisoned more than four hundred people. ${ }^{13}$

9 On this issue, see Pascale Trompette, Mélanie Lemonnier, "Funeral Embalming: The transformation of a medical innovation," Science Studies 22 (2009): 9-30, on 9-14.

Robert Christison, "Observations on the Duration of Cholera, the Taste of Arsenic, and its Power of Preserving the Decay of the Bodies of Those Poisoned with it," Edinburgh Medical and Surgical Journal 28 (1827): 94-110, on 102-104, quote on 104.

Alphonse Chevallier, "Sur la coloration des poisons," Journal de chimie médicale 12 (1836): 6oo-609, on 605; Chevallier explains that the mixture for "chaulage" was made of 6 parts of white arsenic and 2 of alum.

Jean-Baptiste Boussingault, "Sur l'opportunité de faire intervenir l'arsenic dans le chaulage des grains," Annales de chimie 46 (1856): 458-472 ; "En définitive, le chaulage doit avoir deux buts: l'un de préserver la récolte de la carie, l'autre de la soustraire à la voracité des animaux nuisibles", quotation on 46o; Frederic W.J. McCosh, Boussingault: Chemist and agriculturist (Dordrecht: Kluwer, 1984), 155.

On France see Nathalie Jas, "Publich Health and Pesticide Regulation in France before and after Silent Spring," History and Technology 23 (2007): 369-388; William R. Cullen, Is 
White arsenic was commonly employed in rural life during the 1830 s as rat poison, so when a person was put on trial under suspicion of a poisoning crime, the defense frequently alleged that the defendant had indeed bought arsenic for making "mort-aux-rats." There were no strict regulations concerning its commerce and it was acquired in apothecary shops all over France. Poisons only had to be in a "locked and separated" space under the surveillance of the apothecaries, who were requested to limit access to "well-known people" who could justify the use for "their profession" or other reasons. ${ }^{14}$ The broad range of uses of arsenic made this restriction useless in practical terms, even if it somehow denied access to indigents, prostitutes, beggars and other destitute people. They could hardly enter an apothecary shop and ask for arsenic to use as rat poison. This is one reason why the profile of poisoners was so different from other common criminals during the nineteenth century, and not only from the point of view of gender. Many poisoners were respectable people who had never been imprisoned. Some of them were relatives or close friends of the victims, so they could easily obtain poison for domestic use and administer it at home without raising suspicion.

Nineteenth-century regulations also requested apothecaries to keep track of the commerce of all poisonous substances, including arsenic. These documents reveal that some defendants in poisoning trials could obtain large quantities of white arsenic without raising major suspicions. One of the most famous of them, Marie Lafarge, could easily acquire around one hundred grams of white arsenic (the lethal human dose is sometimes less than one gram) in three different purchases made in apothecary shops during December 1839 and January 1840 . She was so confident of being unsuspicious that she included the following sentence in one of her letters to the apothecary: "Don't think that I want to poison the whole region of Limousin."15 Criminal records confirm that many other defendants could easily purchase arsenic in apothecary shops. The following year, another woman accused of poisoning three direct relatives, Marie Bernardou, bought thirty grams of arsenic in an apoth-

Arsenic an Aphrodisiac? The sociochemistry of an element (Cambridge: RSC, 2008), 61-67.

14 The regulations are printed in Adolphe Trebuchet, Jurisprudence de la médecine, de la chirurgie et de la pharmacie en France (Paris: Baillière, 1834), 615-617. See also Guy Devaux, "Marchands de mort-aux-rats," Revue d'histoire de la pharmacie 92 (2004): 509-516.

15 Archives Départementales de La Corrèze (ADC), 5U88, Testimony of Jean-François Lafosse, witness number 39. His son was also interrogated (witness number 26). The register of the apothecary Eyssartier was presented during his testimony in court. See ADC, 5 U88, witness number 22. More details in José Ramón Bertomeu Sánchez, La verdad sobre el caso Lafarge. Ciencia, justicia y ley durante el siglo XIX (Barcelona: El Serbal, 2015). 
ecary shop. Again, the information was kept in a register, which was offered to the judge during the trial. ${ }^{16}$

After the "wave of poisoning crimes" which took place at the end of the 1830s, a magistrate and member of the Conseil d'Etat, Louis-Marie de Lahaye, vicomte de Cormerin (1788-1868), asked for more restrictive regulations concerning the commerce of poisons. He recommended that druggists, apothecaries and grocers should no longer be allowed to sell dangerous substances. But he foresaw many difficulties in replacing arsenical compounds with nondangerous substances having a similar range of uses. ${ }^{17}$ The French government was also concerned with the problem and requested expert reports from learned societies. By the middle of 1840 s, new and more restrictive regulations concerning commerce in poisons were adopted in France, similar to the ideas adopted in the British Arsenic Act in 1851. The French decree of 29 October 1846 regulated the sale, purchase and use of poisonous substances, and explicitly forbade the use of arsenical compounds in "the stepping of grains, the embalmment of cadavers and the destruction of insects." 18 The use of arsenic compounds was only allowed for medical or industrial purposes. All arsenical preparations had to be previously approved by learned societies or governmental panels (the Paris School of Pharmacy, Alfort School of Veterinary, Minister of Agriculture, and so on). The effect of these regulations was limited, as the forensic doctor Ambroise Tardieu angrily complained: exceptions in industry and veterinary were frequent, old practices in agriculture were difficult to change and new poisonous substances were introduced without further regulation. ${ }^{19}$

16 Gazette des Tribunaux, 25 Janvier 1841. Another example is the trial of Victorine Jullien accussed of parricide in Ozillac. Requested by the judge, the apothecary "consulted his register" and noted that the purchase took place exactly on December 21, 1838. See Gazette des Tribunaux, 5 May 1839 .

17 Louis-Marie de Lahaye, Mémoire sur l'empoisonnement par l'arsenic (Paris: Pagnerre, 1842), 25-28.

Louis Tripier, Les codes collationnés sur les éditions officielles (Paris: Cotillon, 1852), 13441345 .

19 More details on the regulation of poisoning substances in France during the nineteenth century are in Ambroise Tardieu, Étude médico-légale et clinique sur lempoisonnement, (Paris: Baillière, 1875), 150-162; On England and the "arsenic act" see Peter Bartrip, "A "Pennurth of Arsenic for Rat Poison": The arsenic act (1851) and the prevention of secret poisoning," Medical History 36 (1992): 53-69; On India, see David Arnold, Toxic Histories: Poison and pollution in modern India (Cambridge: Cambridge University Press, 2016) (I am grateful to the author for sending me a preliminary version of a chapter). 


\section{Elusive and Misleading: Fallacies of the Senses and Chemical Essays}

The popularity of arsenic during the nineteenth century was not only due to its ubiquity and broad use in everyday life, combined with "the easiness with which it could be obtained in stores." 20 Its features also fatally encouraged its use by criminal hands. These included its effects inside the human body, its resemblance to other common domestic products and its mild flavor, which could be masked in soups and drinks when administered to the victim. ${ }^{21}$ All these features, along with the ambiguities and uncertainties of detecting methods, transformed arsenic into the "king of poisons" during the first half of the nineteenth century.

The flavor of arsenic was supposed to be mild, even if, for obvious reasons, information about this point was scarce. In fact, toxicologists disagreed regarding the best way of characterizing this property. The most famous British toxicologists, such as the Edinburgh professor Robert Christison (1797-1882), performed risky self-experiments in which he placed the poison on his tongue "as far back as we thought safe" and concluded that arsenic had "hardly any taste at all."22 In contrast, his French colleague Mateu Orfila (1787-1853), and many other authors such as Foderé or Thenard, described the flavor of arsenic as "acrid" whereas other authors described it as having a "nauseous sweetish taste."23 Be that as it may, the flavor was easily masked by food and drink, and victims rarely detected the existence of the poison in meals before it was too late. Accidents were frequently reported in newspapers. For instance, in a banquet celebrated in Sainte-Menehould, not far away from Luxemburg, a large number of participants relished a tasty beef stew, which had mistakenly been seasoned with arsenic after being cooked in an oven. Nobody realized that the white powder was not salt or pepper but white arsenic. Only a few of the poisoned guests remembered perceiving a "disgusting taste similar to sour apples. ${ }^{24}$

20 Alphonse Devergie, Médecine légale théorique et pratique (Paris: Germer-Baillière, 1840), vol. 3, 414 .

21 Lahaye, Mémoire, p. 18 (see note 17).

22 Whorton, The Arsenic Century, p. 62 (see note 2).

23 Robert Christison, "Observations on the Duration of Cholera," quoted on p. 96 (see note 10); On the different views concerning the flavor of arsenic see Charles Flandin, Traité des poisons (Paris: Bachelier, 1846-1853), vol. 1, 515.

24 Devergie, Médecine légale, vol. 3, p. 414 (see note 20); See also René Lecanu, Adolphe Chevallier, "Rapport sur la nécessité de colorer les substances toxiques dans le but de prévenir 
Another dangerous feature of arsenic was its white color and texture, which could be confused with many ordinary products such as salt, carbonates, sugar, or flour. The resemblance caused many dreadful accidents such as the ones previously mentioned. Many accidents (sometimes involving children) were reported in cases where mixtures of arsenic were confused with sugar or salt. The difficulties of reconnaissance also applied to doctors or even would-be poisoners. For instance, a woman (who apparently wanted to kill her daughter) obtained in 1835 the poison from a colporteur, but she requested him to check the nature of the white power and the colporteur poisoned a cat in front of her. The confusion created many embarrassing situations during criminal investigations. When suspicions were raised, any white and tasteless powder could be mistaken for arsenic. During the 1830s, many authors suggested adding pigments to white arsenic as a way to single it out from similar materials, in order to reduce both poisoning accidents and crimes. ${ }^{25}$

Another means for detecting arsenic was the nose: metallic arsenic released a garlic-like smell when sublimated. Many other chemical products were detected by the nose in nineteenth-century laboratories, for instance, lead acetate (with an odor similar to vinegar) and prussic acid (bitter almonds). As Lissa Roberts has remarked, the uses of the senses in chemical practice was broad and diverse: nineteenth-century chemists never "stopped smelling, tasting, touching, or listening in the service of their analytical activities." 26 Even if broadly employed, the sense of smell was far from being fully appreciated by toxicologists and forensic doctors, at least when credible claims had to be presented in court. The famous French toxicologist Mateu Orfila admitted having once deceived himself by his nose when performing an analysis with Nicolas Vauquelin during a poisoning trial in which arsenic was never found by means of chemical tests. He included in his textbook this cautionary tale for disapproving what was a common practice among doctors: they reported an arsenic

les empoisonnements," Annales d'hygiène publique et de médecine légale 24 (1840): 264283, on $278-279$.

25 Gazette des Tribunaux (14-15 Septembre 1835): 1098; The other examples are reported in Adolphe Chevallier, "Sur la coloration des poisons," Journal de chimie médicale 12 (1836): 6oo-6og; See also Émile Grimaud, "De la coloration de l'acide arsénieux," Bulletin de l'Académie de Médecine 5 (1840): 403-418.

26 Lissa Roberts, "The Death of the Sensuous Chemist: The new chemistry and the transformation of sensuous technology," Studies in History and Philosophy of Science 26 (1995): 503-529, quoted on 507 . 
poisoning case just because "they had found in the digestive tract a substance which spreads [when heated] a garlic-like odor."27

In spite of these warnings, the smell test was so popular that even common people performed it at home when suspicions were raised. During the Lafarge trial, relatives and friends of the victim affirmed that they had performed the smell test during the days before the death of Charles Lafarge. They took samples of drinks and meals, placed them over burning charcoal and perceived a garlic-like aroma, which they regarded as a confirmation of their worst fears. Neither of them had any previous training in chemistry or medicine, which suggests that the smell test was very popular at this time, even outside the academic community. ${ }^{28}$ Moreover, continued criticism in academic writings suggests that the smell test was also widely used by local doctors and apothecaries during criminal investigations all through the nineteenth century. ${ }^{29}$

\section{Colorful Tests and Black Stains}

Arsenic could also be detected in toxicological research by means of a large group of chemical reagents yielding characteristic colors and precipitates. As Ernst Homburg has shown, the methods of analytical chemistry experienced a substantial change between 1780 and 1840 . New ideas of chemical composition were developed alongside changes in material culture, the reduction of vessels and samples, new test tubes, and further sophistication and more sensitivity in analytical methods. More recently, Catherine M. Jackson has remarked that these changes were prompted by a "glassware revolution" which took place at the beginning of the nineteenth century. The changes involved a new material environment based on glass and its properties (inertness, transparency, and malleability), which prompted a new array of laboratory practices and the spread of small-scale apparatus, which could be made by professional or

27 Mateu Orfila, Traité des poisons, (Paris: Crochard, 1826), vol. 1, 357; See also Mateu Orfila, "Rapport médico-légal servant de base à une accusation d'empoisonnement par l'arsenic," Annales d'hygiène publique et de médecine légale 2 (1829): 405-430; For more details on smells and legal medicine in nineteenth century, see José Ramón Bertomeu-Sánchez, "Smell, Chemistry and Microscopy: Bloodstains and nineteenth-century forensic medicine," Annals of Science 72 (2015): 490-516.

28 ADC, 5 U88. Testimony of Anna Brun and Marie-Josephine-Aména Buffière.

29 François-Vincent Raspail, Accusation d'empoisonnement par l'arsenic (Paris: Gazette des Hôpitaux, 1840), 33; Mateu Orfila et al., "Triple accusation d'empoisonnement: condamnation à la peine de mort," Annales d'hygiène publique et de médecine légale 28 (1842):107-192, on 110-111. 
even amateur chemists with the required skills in glass tube-making. ${ }^{30}$ During the following decades, the new tests were systematized and the reagents were "increasingly seen as parts of a single, highly versatile comprehensive methodology $[. .$.$] for investigating the chemical composition of a substance."31$ During the first third of the nineteenth-century, these analytical techniques were organized in handbooks and special volumes on chemical analysis were published. ${ }^{32}$

Chemical tests were regularly employed for toxicological research. Crime scenes were a constant source of uncertainties and challenges, involving large amounts of unknown impurities, misleading side-reactions involving complex organic products, and requiring high standards of proof for supporting verdicts, sometimes involving the death penalty. First of all, a sample had to be taken from meals, vomits or liquids found in the stomach of the victim. If looking for mineral poisons, samples were usually treated first with acids in order to destroy organic substances, then boiled in water, and the extracts submitted to the action of particular reagents. In the case of arsenic, the most common reagent was hydrogen sulfide, which was supposed to yield a characteristic yellow precipitate when the sample contained arsenic even in very small quantities. This test posed practical problems, the most important being its slowness. Some authors reported having waited hours or even days for the yellow precipitate to be formed. ${ }^{33}$ If they were not patient enough, experts could be led astray by the lack of yellow precipitates and might wrongly conclude that there was no arsenic in the analyzed samples. Indeed, a number of such mistakes were reported in contemporary toxicological papers. ${ }^{34}$

More problems arose from ambiguities in the identification of colors, which could turn into false negatives or, even worse, false positives. The transmission of information concerning colors was always complex in the black-and-white

30 Catherine M. Jackson, "The "Wonderful Properties of Glass": Liebig's Kaliapparat and the practice of chemistry in glass," Isis 106 (2015): 43-69; For another example of the relevance of the new glass instruments, see the essay by Serrano in this volume.

Ernst Homburg, "The Rise of Analytical Chemistry and its Consequences for the Development of the German Chemical Profession," Ambix 46 (1999): 1-32, quoted on 3.

An example in France is Jacques Thenard, Traité de chimie, (Paris: Crochard, 1813-1816); This textbook became the most important reference book in France. See Antonio García Belmar and José Ramón Bertomeu-Sánchez, "Louis Jacques Thenard's Chemistry Courses at the Collège de France, 1804-1835," Ambix 57 (2010): 48-63.

33 Alexander Bussy, Charles P. Ollivier and Mateu Orfila, Réponse aux écrits de M. Raspail sur l'affaire de Tulle (Paris: Béchet, 1840), 24.

34 Mateu Orfila, "Affaire d'empoisonnement portée devant la cour royale de Maine-et-Loire," Annales d'hygiène publique et de médecine légale 9 (2) (1833): 410-417, on 414-415. 
world of chemical literature, so toxicologists faced similar problems to other authors working in areas in which colors played a major role in the nineteenthcentury. ${ }^{35}$ The identification of characteristic tones required many hours of practical work at the laboratory and the mastering of a sophisticated chromatic language. A flavor of the copious language of colors is provided by the following examples taken from the section on arsenic in a popular nineteenth century toxicological textbook: "brownish-red colour", "yellowish-brown muddiness", "a crumbly, foliaceous mass, having a pearly lustre", "bluish-white precipitate", "a yellow colour with a faint tint of orange."36

Critics pointed out the difficulties of dealing with slight color nuances, whose identification largely depended on the training, experience and visual skills of experts as well as the rather capricious aptitudes of their organs of vision. François-Vincent Raspail (1794-1878), one of these critics, affirmed that "phenomena related to coloration" were very much "illusory and variable." ${ }^{37} \mathrm{In}$ a similar vein, Adolphe Devergie (1798-1879), a toxicologist with much experience as a forensic doctor in poisoning trials, asserted in his authoritative textbook on legal medicine, that "nothing can be less certain than the colour of a precipitate. The same colour can offer ten different nuances; four people examining the colour of a precipitate can find four different colours." ${ }^{38}$

Chemical tests faced many other problems related to the undisciplined nature of crime scenes. Even tiny quantities of organic substances could generate masking-effects altering the final color of solutions and precipitates. Moreover, yellow precipitates (similar to those obtained with arsenical samples) could be obtained with many non-arsenical compounds, and dangerously misled experts into false positive conclusions. The risks depended both on the employed methods and the background, skills and experience of the experts. Each test involved not only particular skills, but also different standards of

35 One of these areas was obviously spectroscopy. See Klaus Hentschel, Mapping the Spectrum: Techniques of visual representation in research and teaching (Oxford: Oxford University Press, 2002); and, in more general terms, his later book Klaus Hentschel, Visual Cultures in Science and Technology (Oxford: Oxford University Press, 2014).

36 Robert Christison, A Treatise on Poisons (Edinburgh: Adam Black, 1832), 258-26o.

37 François-Vincent Raspail, "Sur les moyens, soit chimiques, soit microscopiques, qu'on a tout récemment proposés pour reconnaître les taches de sang en médecine légale," Journal général de médecine, de chirurgie et de pharmacie 102 (1828), 335-350, quoted on 335.

38 Alphonse Devergie, Médecine légale théorique et pratique (Paris: Baillière 1852), vol. 3, 17-18: “Rien n'est moins certain que la coloration d'un précipité; qu'un même couleur peut offrir dix nuances différentes; que quatre personnes examinant la couleur d'un précipité pourront lui trouver quatre couleurs différents." 
proof and forms of evidence, which could be more or less suitable in courts, where the results had to be presented to judges, lawyers and jurors. ${ }^{39}$

All these issues become evident in reviewing the first years of the Marsh test for arsenic, which is commonly regarded as a landmark in the history of analytical chemistry. In fact, its introduction by no means eradicated previous methods, including other similar reduction tests. Moreover, the apparatus imagined by James Marsh in 1836 was substantially modified by chemists and toxicologists in subsequent years. It was a good example of the plasticity of the new small-scale glass apparatus. It required only a cheap, easy-to-construct vessel, but involved hours of practice and advanced laboratory skills to use. The sample was placed in a flask with zinc and sulfuric acid. If the sample contained arsenic, a thin metallic film was obtained on a porcelain vessel. ${ }^{40}$

There were two alleged advantages to the Marsh test: its capacity for providing "plain matters of fact" and its high sensitivity. In contrast with clinical symptoms, post-mortem examinations or color chemical tests, the Marsh test provided a material form of proof, namely the arsenical black stains obtained on a porcelain vessel, which seemed "to speak for itself" without the mediation of experts and could be dramatically presented in court as the corpus delicti. Toxicologists employed these dramatic effects not only in courts but also in classrooms and academies. ${ }^{41}$ The second major advantage was its high sensitivity ("beyond any imagination" according to Justus Liebig). When skilled hands were at work, the Marsh test could detect minute amounts of arsenic, which would have remained unnoticed by earlier tests. ${ }^{42}$

The advent of the new test encouraged the marginalization, but never a complete abandonment, of previous methods for detecting arsenic. Like DNAfingerprints in the 1990s, the Marsh test was employed for unveiling the fallacies and exploring the limits of previous toxicological methods (such as color tests). The introduction of the new test fueled expert controversies with the unwanted result of questioning toxicology in general and the authority of particular

39 On this issue, see Ian Burney, Poison, Detection, and the Victorian Imagination (Manchester: Manchester University Press, 2006).

For further details concerning the Marsh test see José Ramón Bertomeu-Sánchez and Agustí Nieto Galan, eds., Chemistry, Medicine, and Crime: Mateu J.B. Orfila (1787-1853) and his Times (Sagamore Beach, MA: Science History Publications, 2014); On the "glassware revolution" see Jackson, "Wonderful Properties of Glass" (see note 30).

Robert Christison, A Treatise on Poisons, fourth edition (Edinburgh: Black, 1845), 261; See also Ian Burney, "Languages of the Lab: Toxicological testing and medico-legal proof," Studies in History and Philosophy of Science 33 (2002): 289-314. room: Normal arsenic and nineteenth-century toxicology," Isis 104 (2013):197-225. 
experts in courts. In contrast with DNA fingerprints, the controversy over chemical tests never reached a closure by the emergence of new technologies granted with "exceptional evidentiary status." 43 The controversies lasted for several decades and, in some cases, moved beyond the French medical community to be part of conversations in salons and other spaces of popular culture.

\section{Expert Controversies in Courts}

Expert controversies were encouraged not only by the co-existence of different chemical tests in toxicological practice. ${ }^{44}$ Other forms of proof were also commonly employed by forensic doctors (for instance, clinical symptoms and post-mortem examinations) and sometimes this medical information was at odds with the conclusions of chemical tests. The different background, experience and location of experts also fueled many controversies. In general terms, local doctors tended to rely on clinical symptoms and autopsies, in part because they had privileged access to these data. Local apothecaries were usually requested to perform chemical tests, while experts from Paris participated in just a few of the trials, notably when different or inconclusive results were obtained by the local experts. Apart from disciplinary barriers, the heterogeneous group of nineteenth-century experts on crime was affected by huge inequalities concerning laboratory resources and academic power.

According to the French Criminal Code, the examining magistrate ("juge d'instruction") had to be assisted by one or two physicians when a violent death was suspected. Under oath, the experts produced a written report answering the questions of the magistrate concerning the circumstances and nature of the crime. At the local level, even officiers de santé (the lowest category of French doctors) could participate as experts in a trial. In most cases, many of the local experts were the victim's doctors and sometimes they participated in courts as both experts and as regular witnesses. When reports were inconclusive or different points of view were expressed, judges might request

43 The previous quotation was taken from the study on DNA fingerprints in Michael Lynch et al., Truth Machine: The contentious history of DNA fingerprinting (Chicago: University of Chicago Press, 2008), 340.

44 The co-existence of different tests was common in the analysis of many nineteenth-century products. See for instance the tests on the composition and quality of milk (including organoleptic properties, tube tests and scientific instruments) in Peter Atkins, Liquid Materialities: A history of milk, science and the law (Surrey: Ashgate, 2010). 
new tests from another group of experts, or might accept proposals in that sense from the defense or the prosecution. As a result, the participation of several experts and the existence of multiple reports with opposing conclusions was far from unusual in French courts. ${ }^{45}$

Some examples demonstrate how expert controversies arose in courts. In 1834, a young woman, Zélie Pejac, was accused of having poisoned her employer in the small city of Eauze (Southwest France, near Toulouse). The victim had experienced violent vomiting followed by sudden death after having ingested a meal prepared by the defendant. A local physician ("officier de santé") and an apothecary performed an autopsy concluding that the victim had succumbed to the effects of arsenic. Another group of experts, which included physicians and apothecaries from the neighbouring village, was asked to produce a new report. They "unanimously" concluded that "there was a complete absence of any arsenical substance." In this case, the chemical proofs (mostly negative) were contrary to the medical evidence based on symptoms and autopsy (mostly positive). The young woman was acquitted but, under the pressure of the trial, she lost her mind and went insane. ${ }^{46}$

Apart from the magistrates, defense lawyers could also contact additional experts when they thought that the reports were "incomplete, biased, or contrary to the principles of the art." Without the constraints of official reports, these "consultations" easily turned into long research papers, sometimes published in medical journals. ${ }^{47}$ Consultations also opened the window to the participation of experts without credentials, including those who were on the fringes of the academic world or even radical critics such as Raspail. He was rarely requested as an expert by judges during poisoning trials, in part because he never received the title of medical doctor or pharmacist. Another reason was his political activism. Raspail spent years in prison for his opposition to the French monarchy. Lacking academic degrees, experimental skills and laboratory resources, Raspail relied on skeptical arguments about toxicological methods and the limits of scientific proofs in criminal justice to make his arguments.

45 For more information about expert reports and the French legal system, see Frédéric Chauvaud, Experts et expertise judiciaire: France, XIXe et XXe siècles (Rennes: PUR, 2003), 192-198; The participation of multiple experts was also common in forensic psychiatry. See Laurence Guignard, Juger la folie. La folie criminelle devant les assises au XIXe siècle (Paris: PUF, 2010), 244, which mentions a trial in which ten different experts participated. See also 233 and 241-242; For more details see Bertomeu Sánchez, La verdad sobre el caso Lafarge, chapter 4 (see note 15).

46 Gazette des Tribunaux (11-12 August 1834).

47 Mateu Orfila, Leçons de médecine légal (Paris: Béchet jeune, 1823), vol. 1, 36-7. 
One of the most repeated critical arguments against the new high-sensitivity methods (such as the Marsh test) concerned ironically the small quantities of arsenic detected in the analysis. In this "homeopathic legal chemistry" it was hard to avoid all possible sources of minute impurities found in reagents and vessels, graveyard soils, and so on. ${ }^{48}$ The most challenging of these impurities was the so-called "normal arsenic", that is, the tiny amount of arsenic which was supposed to exist in normal - that is, non-poisoned- human organs. Playing with the ubiquitous nature of arsenic in nineteenth-century France, Raspail employed his creative imagination to suggest as many potential sources of arsenic contamination as possible. Arsenic might be passed onto buried corpses by natural forces which chemical experiments at the laboratory were unable to detect. Or perhaps unknown phenomena taking place during the process of putrefaction might spread the insidious normal arsenic from the bones to other parts of the corpse, making it a dangerous source of false positives. False positives were much more likely when using high sensitivity tests than when old methods were employed. ${ }^{49}$

Raspail employed more general epistemological questions concerning the differences between legal and scientific evidence. He highlighted tensions between the open-ended character of scientific research and the necessary closure and irreparable consequences of legal decisions, particularly in cases in which the life of the defendant was at stake. In the midst of a famous poisoning trial, Raspail affirmed: "Gentlemen, you must doubt the omnipotence of legal chemistry because it refutes itself every six months." ${ }^{50}$ Even granting that all known sources of error had been considered, Raspail wondered who could positively affirm that subsequent studies would not discover new fallacies and problems in toxicological methods. After a death sentence, Raspail argued, who could restore the guillotined head of the defendant when the chemical error was finally acknowledged? In stressing these points, Raspail's skepticism regarding scientific evidence was in tune with growing concerns about judicial errors in French legal writings during the nineteenth century. ${ }^{51}$

It was not the technicalities of chemical tests, but wide-ranging concerns raised by critics such as Raspail which helped to move the controversy from courts and academies to the public arena. Raspail was willing to transport the

48 The expression was employed in an anonymous essay published in American Journal of the Medical Sciences 2 (October 1841), 403-417, quoted on 414.

49 See Bertomeu-Sánchez, "Managing Uncertainty"(see note 42).

50 Gazette des Hôpitaux (31 December, 1839): 609.

$5^{1} \quad$ On the growing concern about judicial mistakes, see Chauvaud, "Experts et expertises", pp. 230-240 (see note 45). 
debate to these new scenarios, whereas other experts were clearly against this circulation, maybe realizing that it was dangerous for their authority. In the midst of a fierce debate in court concerning the value of tests for arsenic, Raspail was challenged to present his conclusions before the members of the Paris Academy of Medicine, where his claims could be "judged by competent men." Raspail soon answered with a letter to the journals, announcing that he was willing to accept the challenge, but not in front of the members of the Academy of Medicine. "The judge," according to Raspail, should be "all the people, the public."52

\section{From Courts to Academies and Salons}

Although just a small percentage in the total number of murders in nineteenthcentury France, poisoning crimes attracted a great deal of public attention. Courtrooms were crowded with large and varied audiences who avidly followed the hearings and the rather dramatic expositions of prosecutors and lawyers. The participation of local physicians or apothecaries aroused further interest, and even more when the experts were famous doctors or toxicologists from Paris. Public attention was also captured by the mysterious circumstances of the crime, the uncertainties regarding verdicts, and not the least, the embarrassing details disclosed by criminal investigations of the victims' or defendants' private lives. Newspapers often reported on these trials, sometimes including documents such as the act of accusation, the plea of the defense, or summaries of the trial offered by journalists. Judicial journals (such as the Gazette des Tribunaux or Le Droit) published verbatim transcriptions of the oral hearings and extracts from the expert reports. When poisoning trials became particularly popular, books and leaflets were published with further details about the protagonists.

The most famous nineteenth-century French poisoning trial took place during September 1840 in Tulle (La Corrèze). At the beginning of this year, Charles Lafarge, the owner of a bankrupted forge, had died after a short illness and his wife Marie was accused of poisoning him. A group of local physicians and pharmacists were consulted. The autopsy offered some evidence of poisoning, but chemical tests were inconclusive due to a common laboratory accident. New analyses were performed by another group of experts from the capital of the department (Limoges), but they could not retrieve any arsenic from the corpse, even when they used the new Marsh test. The judge requested new 
tests performed by a joint group of first and second experts but they were also unable to find traces of arsenic. After a long discussion, the prosecution managed to obtain a fourth, definitive test by a group of experts lead by the most famous French toxicologist, Mateu Orfila (1787-1853). He was the dean of the Paris Medical Faculty, a member of many French advisory committees regarding medicine and education, editor of influential journals, and, last but not least, a well-reputed singer who organized popular musical soirées in his salon, which became a meeting point for musicians, physicians, lawyers, politicians and other French notables during the reign of Louis-Philippe d'Orléans. ${ }^{53}$

The participation of a Parisian celebrity like Orfila sparked the public's interest in the trial of Marie Lafarge even more. Moreover, Orfila introduced an unexpected and dramatic turn in the judicial developments, widely commented upon in newspapers and further publications. Contradicting previous expert reports, Orfila found very tiny quantities of arsenic in the victim's corpse, suddenly dashing the high hopes of the defense opened by previous analysis. In a desperate move, Marie Lafarge's lawyer attempted to contact Raspail, but when he arrived in Tulle the legal proceedings were over and Marie Lafarge had been indicted for murder and, later, imprisoned for life. Raspail, however, wrote a long report contradicting the conclusions of Orfila. Many other popular publications followed, in which public hearing debates were transformed into rather literary reconstructions by journalists and other commentators. Excerpts from medical reports and fragments of dialogs taken from verbatim transcriptions of oral hearings were frequently employed, so providing plausibility or amplifying the dramatic force of the narratives. Many literary genres were mobilized, from autobiographies, letters, articles in newspapers, poems, and theater plays, to different forms of academic literature, including medical papers, proceedings of learned institutions, controversial leaflets and expert reports. A review of some of the publications concerning the Lafarge affair, which appeared in an English magazine in 1841, remarked on the overlapping of fictional, medical and judicial literature dealing with poisoning trials:

We confess to having been singularly interested in [...] the trial of Madame Lafarge for the murder of her husband. As a Romance of Real Life, it strongly exemplified the adage that Truth is stranger than Fiction; for certainly no living dramatist could have invented such a plot, or such characters, or such scenes as occurred in its progress. No extravagant 
German tale ever presented a wilder mixture of the revolting, the horrible, and the ludicrous. It resembled one of our own Terrific Melodramas of strong Tragic Interests. ${ }^{54}$

Thanks to these dramatic ingredients, the Lafarge drama soon turned into a trending topic in French salons. Many other circumstances contributed to the outstanding popularity of this affair. First, the extraordinary biography of Marie Lafarge, a well-cultivated Parisian woman who was a friend of the writer Alexandre Dumas and other French notables, and so hardly representative of the poor and unknown people who were placed on the bench of the accused. Her autobiography, published shortly after the trial, went through several editions and several translations appeared during the nineteenth century. The translations, the reports by journalists, and the publication of many polemical texts by forensic doctors and lawyers, helped to expand interest in this affair to other countries. The prosecutor could affirm in court that the trial had captured the attention of the "whole [of] Europe." Celebrated writers such as Heinrich Heine, Alexandre Dumas, Gustave Flaubert and many other authors wrote thousands of pages on the issue. ${ }^{55}$

The fame of the experts (such as Orfila and Raspail), who were involved in a fierce controversy, was an additional reason for the popularity of the trials. Their opposition emerged for both scientific and political reasons. Raspail was a wellknown Republican activist whereas Orfila was a good representative of the group of notables supporting the new Orleanist monarchy. The public who followed the poisoning trials could not help mixing these political battles with the debates concerning the reliability of chemical tests for arsenic. French public opinion was divided into two groups: those supporting the innocence of Marie Lafarge and those accepting the guilty verdict. In general terms, most of the members of the first group were also Republican or, at least, critics of the Orleanist monarchy (like Raspail), while the second group mostly included people who accepted the political order (like Orfila). At the same time, these positions involved contrasting views concerning toxicological methods. The first group were more willing to hear the criticism of Raspail against the new high-sensitivity tests for arsenic prompted by Orfila. On 14 September 1840, almost at the same time that Orfila presented his surprizing final report in the

The New Monthly Magazine 3 (1841): 268; On the connections between literature and crime fiction, see Lawrence Frank, Victorian Detective Fiction and the Nature of Evidence: The scientific investigations of Poe, Dickens, and Doyle (London: Palgrave, 2003) and Burney, Poison (see note 39).

Bertomeu Sánchez, La verdad sobre el caso Lafarge (see note 15). 
court of Tulle, the duchesse de Dino noted in her diary that all conversations in the salons were on the affair Lafarge. "Here," she wrote, "as everywhere, there are quite contrasting views on this issue." 56 The situation was captured by Flaubert in one of the first passages of Sentimental Education. The hero of the novel, the young Frédéric Moreau, who had just graduated and was about to start his studies of law in September 1840, was invited by his mother to have dinner in her house in Nogent-sur-Seine, a village situated a hundred kilometers east of Paris:

When he [Frédéric] entered the drawing-room, all present arose with a great racket; he was embraced; and the chairs, large and small, were drawn up in a big semi-circle around the fireplace. M. Gamblin immediately asked him what was his opinion about Madame Lafarge. This case, all the rage at the time, did not fail to lead to a violent discussion. Madame Moreau stopped it, to the regret, however, of M. Gamblin; he deemed it serviceable to the young man in his character of a future lawyer, and, nettled at what had occurred, he left the drawing-room. ${ }^{57}$

These violent discussions in salons encouraged the popular interest in the chemistry of arsenic. In November 1840, just a few weeks after the guilty verdict, the large amphitheater of the Paris Faculty of Medicine was crowded by a varied audience following Orfila's experiments on arsenic. During this time, a Parisian pharmacist organized a soirée at which he explained in front of some twenty people, "all the experiments regarding arsenic poisoning," reconstructing the chemical analysis performed by the experts during the Lafarge trial and supporting Orfila's views on this issue. ${ }^{58}$

The polemical writings of Raspail were also addressed to this popular audience. As noted above, he offered not only technical details concerning the chemistry of arsenic and its methods of detection, but also dramatic details of the story (which he regarded as proofs of the innocence of Marie Lafarge) and bitter criticism against the all-mighty academic power of his opponent, Orfila. His claims could be found in newspapers, letters and fictional works in this period. One of the most popular arguments concerned the tensions between the ubiquity of arsenic and the minute quantities of poison detected by the Marsh test. When such minute quantities were involved, it seemed that arsenic

\footnotetext{
56 Quoted by Anne Martin-Fugier, La vie élégante ou la formation de Tout-Paris, 1815-1848 (Paris: Fayard, 1990), 170-71.

57 Gustave Flaubert, Sentimental Education (Kent: Wordsworth, 2003), 12-13.

$5^{8} \quad$ L'Esculape (19 November 1840): 125-126.
} 
could be found everywhere, making the results of chemical tests either inconclusive or dangerously misleading. The writer George Sand, who like many others passionately followed the news of the Lafarge trial, affirmed that positive results in chemical tests was far from being reliable proof of poisoning crimes. "Maybe Orfila will discover in the next six months that arsenic does exist in the liver or in the brain of all corpses." ${ }^{59}$ Combining the ubiquity of arsenic with the power of high-sensitivity tests, it seemed that arsenic could "be found everywhere", as Gustave Flaubert remarked in his unpublished Dictionary of received ideas, in a brief paragraph on arsenic. Similar concerns were conveyed in the engraving by Honoré Daumier published around 1841, in which Orfila says: "I am so sure of my facts that now I am going to poison my intimate friend [...] and I will find arsenic in his spectacle lenses." If self-assured experts could detect arsenic everywhere, what was the probatory value of the Marsh test in courts? ${ }^{60}$

The German poet Heinrich Heine (1797-1856), who was exiled in Paris in 1840, offers another example of the varied reactions caused by the trial of Marie Lafarge. Like many other left-wind activists, Heine employed the controversy in order to question the bourgeois order implemented by the Orleanist monarchy in France, in which Orfila occupied such a prominent position. Heine disqualified Orfila as "a flatterer of the powerful people and detractor of the oppressed ones", "as false in his talk as in his singing" (ironically referring to Orfila's fame as singer in salons). According to Heine, the poison was not in Charles Lafarge's remains but in "Orfila's heart." However, he was hardly convinced of the innocence of Marie Lafarge. Indeed, he thought that she had committed a desperate act of "legitimate defence" against a rude and cruel husband who had condemned her to many "moral torments and mortal deprivations." Heine aimed to transform this affair into a starting point for revisiting the situation of women in France. ${ }^{61}$

59 George Sand's Letter to Eugène Delacroix, 22 September 1840, quoted by Chantal Sobieniak, Rebondissements dans l'affaire Lafarge (Paris: Lucien Souny, 2010), 219-220.

6o Chemical Heritage Foundation, Philadelphia, Fine Art Collection (FA 2000.001.142); Whorton, The Arsenic Century, pp. 96-97 (see note 2), quotes a popular English novel by Humphry Sandwith, Minsterborough: A tale of English life (London, 1876), in which the same theme is discussed by an elderly physician "These new-fashioned chemists [...] will find arsenic [...] in your walking-stick; they will indeed. I'll lay my life, sir, that they would extract arsenic from my hat."

61 Heinrich Heine, Lutèce: lettres sur la vie politique, artistique et sociale de la France (Paris: Levy, 1866), 123-126. 


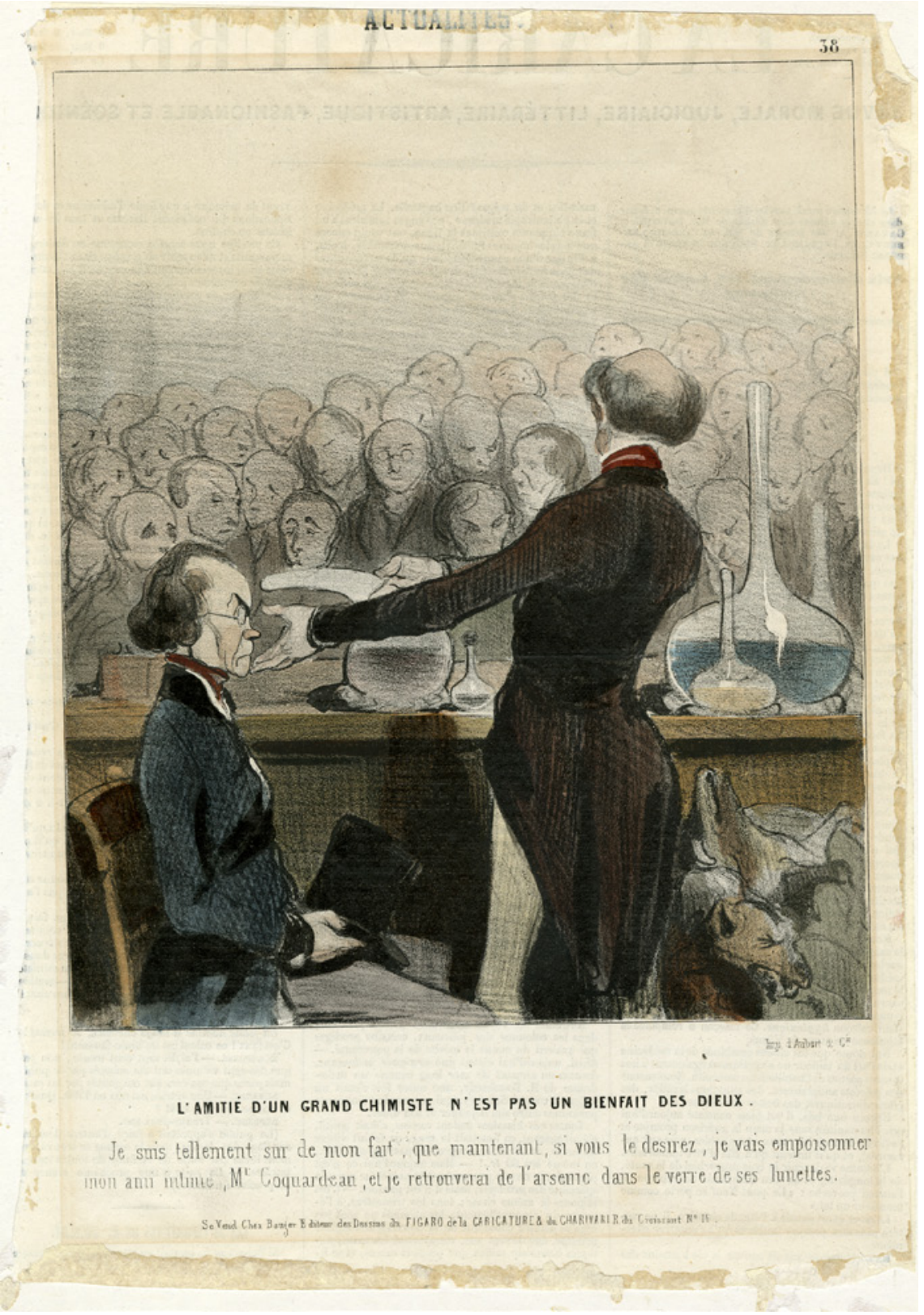

FIGURE 5.1 "L'amitié d'un Grand Chimiste n'est pas un Bienfait des Dieux." Hand-colored lithograph caricature by Honoré Daumier (1841). The character representing Orfila (on the right) affirms, "I am so sure of my facts that now I am going to poison my intimate friend [...] and I will find arsenic in his spectacle lenses." GIFT OF FISHER SCIENTIFIC INTERNATIONAL. CHEMICAL HERITAGE FOUNDATION COLLECTIONS, PHILADELPHIA (FA 2000.001.142).For re-use, contact reproductions@chemheritage.org. 


\section{From Salons to the Courts}

The former examples show how controversies over arsenic detection in courts were intermingled with debates regarding other political and social issues. In this way, poisoning trials created a propitious context for exchanges among popular, legal and medical cultures in nineteenth-century France. Thanks to these exchanges, a large number of people were acquainted with technical details concerning the chemistry of arsenic and the methods for detecting it. In fact, some of the controversial issues were raised in courts by lawyers, magistrates and jurors without any previous training in legal medicine. Experiments on absorption of poisons developed by the French toxicologist Mateu Orfila between 1838 and 1840 offer an example. Orfila pursued a continuing program of research on the absorption of arsenic by using the new possibilities opened by the high sensitivity of the Marsh test. He performed experiments both with poisoned dogs and with samples obtained during criminal investigations from human organs. As his British colleague Robert Christison declared in 1845, his research was "pregnant alike with interesting physiological deductions and valuable medicolegal applications." ${ }^{2}$ Regarding physiological deductions, Orfila attempted to settle old debates concerning the action of poison, opening the window to similar research on medicinal drugs. The main "medico-legal applications" concerned criminal investigations involving long-buried corpses, in which no liquids from the stomach were available and poisons needed to be retrieved from the remains of internal organs (in which poisons could have been absorbed). ${ }^{63}$

Several experiments performed by Orfila convinced him that arsenic might also be found in very small quantities in the bones and organs of non-poisoned animals, what came to be known as the problem of "normal arsenic." In one of these experiments, Orfila prepared a soup with beef and vegetables. After boiling it for seven hours, he took a sample and introduced it to the Marsh apparatus, so obtaining some arsenical black stains. In a letter addressed to the Academy of Medicine in April 1839, Orfila concluded that "if new experiments confirm this result, it will be demonstrated that our everyday beef soups contain an arsenical compound."64

\footnotetext{
62 See Christison, A Treatise on Poisons, pp. 227-228 (see note 41).

63 Bertomeu-Sánchez, "Managing Uncertainty" (see note 42).

64 Bulletin de l'Académie de Médecine 3 (1839), 682: "Si de nouvelles expériences confirment ce résultat, il sera démontré que le bouillon de bœuf que nous prenons tous les jours contient une préparation arsenicale." The soup was made of "cinq livres et demie de bœuf non
} 
Although it was a minor detail in his whole research on normal arsenic, the distressing image of arsenic in regular beef soups was widely commented upon in newspapers and soon captured the public imagination. Unsurprizingly, these frightening results were also employed by Raspail as a proof that arsenic could be found everywhere. Another critic of Orfila's methods creatively transformed the experiment into alarming news for Parisian gourmand when he wrote: "On April 2, 1839, Orfila read at the Paris Academy of Medicine a paper summarizing almost two hundred experiments aimed at demonstrating that the broth consumed in different Paris restaurants was arsenical." ${ }^{65} \mathrm{In}$ fact, these two hundred experiments were on normal arsenic in general, and just one of them was related to soups (which by no means were taken from any Paris restaurant but, as the article indicated, they were prepared by Orfila). However, the image of "arsenic in soups" became so popular that it was even discussed during some poisoning trials at the end of this year:

Judge: "Have you not written that arsenic could be found even in soup?" Orfila: "Yes, it comes from the normal arsenic contained in the bones, but, remarkably, it is never found in the liver; and we found it [arsenic] in the victim's liver." 66

The episode reveals the unwanted consequences of the public interest in toxicological research, poisoning trials and celebrities such as Orfila. Academic meetings were usually discussed in both the medical and popular press and papers on poisons attracted further attention during the years of the famous poisoning trials, at the end of the $1830 \mathrm{os}$. In this situation, a particular and inconclusive animal experiment, when moved from laboratory to the academy and from the academy to the public arena, could be transformed from an esoteric discussion of the absorption of arsenic into a frightening image concerning soups in restaurants. These images were reintroduced in courts by skeptical experts or even by lawyers, judges or jurors who read newspapers with reports on trials or excerpts from academic meetings. This example offers further evidence of how the circulation of information concerning arsenic was multidirectional and involved creative exchanges among different legal, popular

désossé, avec des carottes, des panais, des navet, des poireaux, de l'oignon brûlé, un clou de girofle et du sel."

65 Devergie, Médecine légale, vol. 3, p. 449 (note 20). "Le 2 avril 1839, M. Orfila lut à l'Académie de Médecine un travail résultant de près de deux cent expériences pour démontrer que le bouillon pris dans les divers restaurants de Paris était arsenical." 
and academic cultures. The new high-sensitivity methods for detecting arsenic afforded additional possibilities towards new interactions, introducing new images to be interpreted and discussed.

\section{Conclusion}

Arsenic in nineteenth-century France was simultaneously an object of medical and scientific inquiry, an everyday material employed for multiple purposes, a criminal tool to be detected by toxicologists during legal investigations, and a frightening ingredient in the public imagination, which aroused popular interest in chemical tests and toxicologists. Occupying so many different worlds, nineteenth-century poisons are good examples of "precarious substances" which "have no specific place in any given order of things." They were "essentially characterized by their dynamics" and by the different ways in which their effects "were perceived and framed." ${ }^{7}$ The chemical and medical features of arsenic were crucial insofar as they raised a broad range of opportunities and constraints in connection with the interests, anxieties, and practices of diverse protagonists including physicians, pharmacists, forensic doctors, lawyers, magistrates, journalists, writers, and the general public who crowded courtrooms and perused newspapers looking for information on poisoning trials. The previous discussion offers many examples of the complex mixture of sociomaterial features and cultural representations involved in the history of materials such as arsenic and others studied in this book. From this point of view, arsenic was during the nineteenth-century "the very Proteus of poisons", not only from the point of view of its varied poisonous effects and its elusiveness to chemical tests, but also regarding its place in both academic research and public imagination.

The changing and multiple identities of arsenic were never completely isolated thanks to the frequent transit of historical actors, objects, texts, practices and values from one social setting to another. The diverse experts involved in criminal investigations (forensic doctors, chemists, toxicologists, lawyers and magistrates) played a crucial role in these transits and hybridizations. The role of journalists was also very important insofar as they wrote broadly-read texts, which both answered to and sparked public interest in poisoning trials. Surrounded by a rather theatrical atmosphere, courtrooms were the privileged

67 Viola Balz, Heiko Stoff, Alexander v. Schwerin and Bettina Wahrig, eds., Precarious Matters: The history of dangerous and endangered substances in the 19th and 2oth centuries (Berlin: Max Planck Institute for the History of Science, 2008), 1. 
places for these unequal exchanges among the different cultures of poison during the first half of the nineteenth century. Experts were requested by law to present reports on problems whose frame and focus were far from being under their control. This puzzling situation emerged not only from the impure and undomesticated nature of crime scenes, but also from the unexpected questions asked by judges, lawyers and jurors, who could appropriate the toxicological information provided by experts in very creative ways. As the last section demonstrated, by reading newspapers and judicial journals, lay people could also become acquainted with many details concerning, for instance, chemical tests for poisons and the principal delusions concerning false positives. Expert controversies in courts such as that between Orfila and Raspail generated further attention on poisoning trials and produced a broad range of publications, which contributed to the creative circulation of many details related to the toxicology of arsenic.

These circulations and exchanges had several features, including the ubiquity of arsenic in the nineteenth-century French rural world, the lack of strict regulations concerning its commerce and its elusive and somehow misleading physical nature, and the different methods for detecting it. Many tests co-existed, all of them with particular problems, assumed fallibilities, required skills and areas of uncertainty. Data was obtained by means of medical examinations, post-mortem autopsies, animal experiments and chemical tests. When different methods were employed at the same time, contrasting conclusions might fuel expert controversies. Historians have to take into account the "shock of the old" technologies and their creative interaction with the cutting edge of research in chemical analysis, moving from novelty-focused narratives to use-centered histories of toxicological methods. ${ }^{68}$

At the end of the 1830s, toxicological methods employed in French courts included traditional and very popular methods (such as the smell test), which were never replaced even with the advent of the tube tests and the new high-sensitivity technologies such as the Marsh test. Each method involved uncertainties, dangerous fallacies and particular forms of proof, which had to be converted into credible claims in both academic and legal contexts. Controversies were also fueled by the participation of several group of experts in poisoning trials. "Consultations" created another window for the participation of experts without credentials, including radical critics and activists such as Raspail. They introduced new epistemological concerns about the reliability of scientific proofs in criminal trials and other general topics related to science

68 David Edgerton, The Shock of the Old: Technology and global history since 1900 (London: Profile Books, 2006), xi-xiii. 
and the law. Thanks to their participation in poisoning trials, public debates concerning famous poisoning trials, such as the Lafarge affair, turned into fierce discussions about French politics, the situation of women in France, the role of jurors in poisoning trials and other issues related to criminal law, including death penalty. These debates took place in newspapers and salons and excited even more public interest in details about the toxicology of arsenic, encouraging new publications and even experimental demonstrations in salons and amphitheaters. Many of these publications included literary reconstructions of the most dramatic aspects of the poisoning crimes, along with technical information about new chemical tests and highly polemic issues concerning French politics or the administration of justice. In that sense, poisons such as arsenic created unexpected links and creative exchanges among a heterogeneous range of actors, practices and discourses in different legal, medical and popular settings during the nineteenth-century. Engaging culture and nature in such different ways, the material affordances of arsenic were rather unstable, changeable and unpredictable. 
PART 2

Chemical Governance and the Governance of Chemistry 